\title{
Crop rotation, green manure and nitrogen fertilizers in upland rice under no-tillage ${ }^{1}$
}

\author{
Orivaldo Arf ${ }^{2}$, José Roberto Portugal ${ }^{2}$, \\ Salatiér Buzetti ${ }^{3}$, Ricardo Antônio Ferreira Rodrigues ${ }^{3}$, Marco Eustáquio de Sá ${ }^{2}$
}

\begin{abstract}
The Brazilian Savannah region presents a great potential for the expansion of upland rice crops. However, studies are necessary to identify practices that can improve the crop performance, especially in no-tillage systems. This study aimed to assess the effect of cover crops in association with corn on the development and yield of rice cultivated in rotation and cover fertilized with nitrogen doses. The sprinkler irrigation system was used and the experiment was developed in the 2014/2015 and 2016/2017 harvest years, using a randomized block design, in a $5 \times 4$ factorial scheme. The treatments consisted of the crop remains combinations of single corn crop, corn + Crotalaria spectabilis, corn + pigeon pea, corn + jack bean and corn + Urochloa ruziziensis, as well as cover nitrogen doses $\left(0 \mathrm{~kg} \mathrm{ha}^{-1}, 40 \mathrm{~kg} \mathrm{ha}^{-1}, 80 \mathrm{~kg} \mathrm{ha}^{-1}\right.$ and $\left.120 \mathrm{~kg} \mathrm{ha}^{-1}\right)$ in the rice. The cultivation of upland rice in rotation with corn + pigeon pea was favored by the greater soil cover and nitrogen supply via cycling, if compared to the rotation with single corn crop. The intercropped corn + pigeon pea cultivation in the previous summer resulted in a $15 \%$ increase in the yield of rice grains seeded in the rotation, when compared to the single corn crop. The cover nitrogen application positively influenced the grain yield with the maximum estimated doses of $46 \mathrm{~kg} \mathrm{ha}^{-1}$ and $105 \mathrm{~kg} \mathrm{ha}^{-1}$ of nitrogen, respectively in the $2014 / 2015$ and 2016/2017 harvest years.
\end{abstract}

KEYWORDS: Oryza sativa L.; sprinkling irrigation; Brazilian Savannah.

\section{INTRODUCTION}

Crop rotation systems that produce appropriate amounts of crop residues on the soil surface are essential for ensuring the sustainability of production systems (Silva et al. 2007). Several benefits are derived from crop rotation: maintenance and

\section{RESUMO}

Rotação de culturas e adubação verde e nitrogenada em arroz de terras altas sob plantio direto

A região do Cerrado tem grande capacidade para expansão da cultura do arroz de terras altas. No entanto, são necessários estudos envolvendo práticas que melhorem o desempenho da cultura, principalmente em sistema plantio direto. Objetivouse verificar o efeito de coberturas vegetais em consórcio com milho no desenvolvimento e produtividade de arroz cultivado em rotação e adubado com nitrogênio em cobertura. $\mathrm{O}$ experimento foi irrigado por aspersão e desenvolvido nas safras 2014/2015 e 2016/2017. Utilizou-se o delineamento experimental em blocos casualizados, em esquema fatorial $5 \times 4$. Os tratamentos consistiram da combinação do efeito de restos culturais de milho exclusivo, milho + Crotalaria spectabilis, milho + guandu, milho + feijão de porco e milho + Urochloa ruziziensis, bem como doses de nitrogênio em cobertura no arroz $\left(0 \mathrm{~kg} \mathrm{ha}^{-1}, 40 \mathrm{~kg} \mathrm{ha}^{-1}, 80 \mathrm{~kg} \mathrm{ha}^{-1}\right.$ e $\left.120 \mathrm{~kg} \mathrm{ha}^{-1}\right)$. O cultivo do arroz de terras altas em rotação com milho + guandu foi favorecido pela maior cobertura do solo e oferta de nitrogênio, via ciclagem, em relação à rotação com milho exclusivo. O cultivo de milho + guandu no verão anterior propiciou incremento de $15 \%$ na produtividade de grãos de arroz, semeado na rotação, em relação ao milho exclusivo. A aplicação de nitrogênio em cobertura influenciou positivamente na produtividade de grãos com as doses máximas estimadas de $46 \mathrm{~kg} \mathrm{ha}^{-1}$ e $105 \mathrm{~kg} \mathrm{ha}^{-1}$ de nitrogênio, respectivamente nas safras 2014/2015 e 2016/2017.

PALAVRAS-CHAVE: Oryza sativa L.; irrigação por aspersão; Cerrado.

improvements in soil fertility, diversification of crops in the property, minimization of complete losses risks, maintenance and improvements in crop yield, reduction in production costs and promotion of the rational and efficient use of production factors (Fidelis et al. 2003). Despite these benefits, the adoption of the crop rotation system as the main

1. Manuscript received in Feb./2018 and accepted for publication in Jun./2018 (http://dx.doi.org/10.1590/1983-40632018v4851446).

2. Universidade Estadual Paulista "Júlio de Mesquita Filho", Faculdade de Engenharia de Ilha Solteira, Departamento de

Fitotecnia, Tecnologia de Alimentos e Socioeconomia, Ilha Solteira, SP, Brasil.E-mails: arf@agr.feis.unesp.br, jrp.agrunesp@gmail.com, marcosa@agr.feis.unesp.br.

3. Universidade Estadual Paulista "Júlio de Mesquita Filho", Faculdade de Engenharia de Ilha Solteira, Departamento de Fitossanidade, Engenharia Rural e Solos, Ilha Solteira, SP, Brasil.E-mails: sbuzetti@agr.feis.unesp.br, ricardo@agr.feis.unesp.br. 
production system is still relatively small, mainly due to economic reasons.

Due to the growing demand for rice and the difficulties in expanding irrigated crops in southern Brazil, the study of techniques that allow the introduction of upland rice in no-tillage areas, as an alternative to corn in crop rotation, is necessary (Pacheco et al. 2011). However, the responses of different cover crops should be assessed, in addition to the responses of economically valuable crops used in rotation with rice.

Cover crops, which are used to produce straw in a no-tillage system, play a fundamental role in nutrient cycling (Torres et al. 2008). In addition to maintaining covering and improving the soil attributes, they may benefit subsequent crops. Andrade et al. (2009), studying the physical attributes of a Dystrophic Red Latosol (Typic Hapludox) cultivated with different species of cover crops, concluded that pigeon pea, crotalaria and corn intercropped with brachiaria produced the best physical qualities in the topsoil layer. Similarly, corn intercropped with other species, mainly legumes, may favor the upland rice cultivation by increasing the soil cover and nutrient cycling. Gitti et al. (2012a), in a Dystrophic Red Latosol (Typic Hapludox), also compared the use of different plant species (crotalaria, pigeon pea, millet, crotalaria plus millet, pigeon pea plus millet and brachiaria) in upland rice cultivation and observed a higher grain yield with pigeon pea and a lower yield with brachiaria. The authors attributed this result to the higher nitrogen input by the legume.

Nitrogen is one of the most limiting nutrients for the productivity of upland rice in the Brazilian Savannah region, mainly because the applied nutrient recovery is only $35 \%$, i.e., much of the nitrogen is lost in the system (Fageria et al. 2014). Thus, studies are needed to determine the appropriate nitrogen dose to improve the fertilization efficiency, especially in no-tillage areas that use cover crops. Silva et al. (2016) studied the use of nitrogen fertilizer $\left(0 \mathrm{~kg} \mathrm{ha}^{-1}\right.$, $20 \mathrm{~kg} \mathrm{ha}^{-1}$ and $20+60 \mathrm{~kg} \mathrm{ha}^{-1}$ ) and different cover crops (crotalaria, pigeon pea, mucuna, millet and fallow) with upland rice and found that the rice yield was higher when rice was sown after millet and after the field had lain fallow, situations associated with the highest amounts of applied nitrogen. However, when rice was sown after leguminous cover crops, an increase in rice yield was detected even with an application of only $20 \mathrm{~kg} \mathrm{ha}^{-1}$ of N.

The present study aimed to assess the effect of cover crops intercropped with corn on the development and yield of rice cultivated in rotation and with nitrogen fertilization in a no-tillage system.

\section{MATERIAL AND METHODS}

The experiment was conducted during the agricultural years of $2014 / 2015$ to $2016 / 2017$, in an experimental area (approximately $20^{\circ} 22^{\prime} \mathrm{S}$, $51^{\circ} 22^{\prime} \mathrm{W}$ and $335 \mathrm{~m}$ of altitude) belonging to the Universidade Estadual Paulista, located in Selvíria, Mato Grosso do Sul state, Brazil. The soil of the area, which was originally occupied by Brazilian Savannah vegetation, is classified as a typical clayey Dystrophic Red Latosol (Santos et al. 2013) or Typic Hapludox (USDA 2014), managed under a no-tillage system. The average annual rainfall is $1,370 \mathrm{~mm}$, the annual average temperature is $23.5^{\circ} \mathrm{C}$ and the relative humidity is $70-80 \%$ (annual average).

The accumulated precipitation during the 2014/2015 period from the rice sowing to harvest was $481 \mathrm{~mm}$, with a period of 14 days of warmer weather during the vegetative phase (12/27/2014 to $01 / 09 / 2015$ ). The minimum temperature varied between $18.2{ }^{\circ} \mathrm{C}$ and $24.2{ }^{\circ} \mathrm{C}$, while the maximum temperature oscillated between $26.8^{\circ} \mathrm{C}$ and $39.6{ }^{\circ} \mathrm{C}$ (Figure 1A).

During the 2016/2017 growing season, the accumulated precipitation in the period between the rice sowing and harvest was $628 \mathrm{~mm}$, with warmer weather for 9 days near the flowering phase (02/02/2017 to $02 / 11 / 2017)$. The minimum temperature varied between $19.8^{\circ} \mathrm{C}$ and $24.7^{\circ} \mathrm{C}$ and the maximum temperature between $27.1^{\circ} \mathrm{C}$ and $38.0^{\circ} \mathrm{C}$ (Figure 1B).

The crop rotation system in which the upland rice was introduced began in November 2013, with the cultivation of corn as a single crop or intercropped with cover crops. Common bean was sown in April 2014, rice in November 2014 and, finally, wheat was sown in March 2015, closing the first cycle of the crop rotation. The second cycle occurred during the subsequent years, in the same order as the first cycle, with all treatments being installed on the same plot.

The single corn crop was planted with spacing of $0.90 \mathrm{~m}$ between rows and 5 plants $\mathrm{m}^{-1}$. Crotalaria spectabilis, pigeon pea and Urochloa ruziziensis 

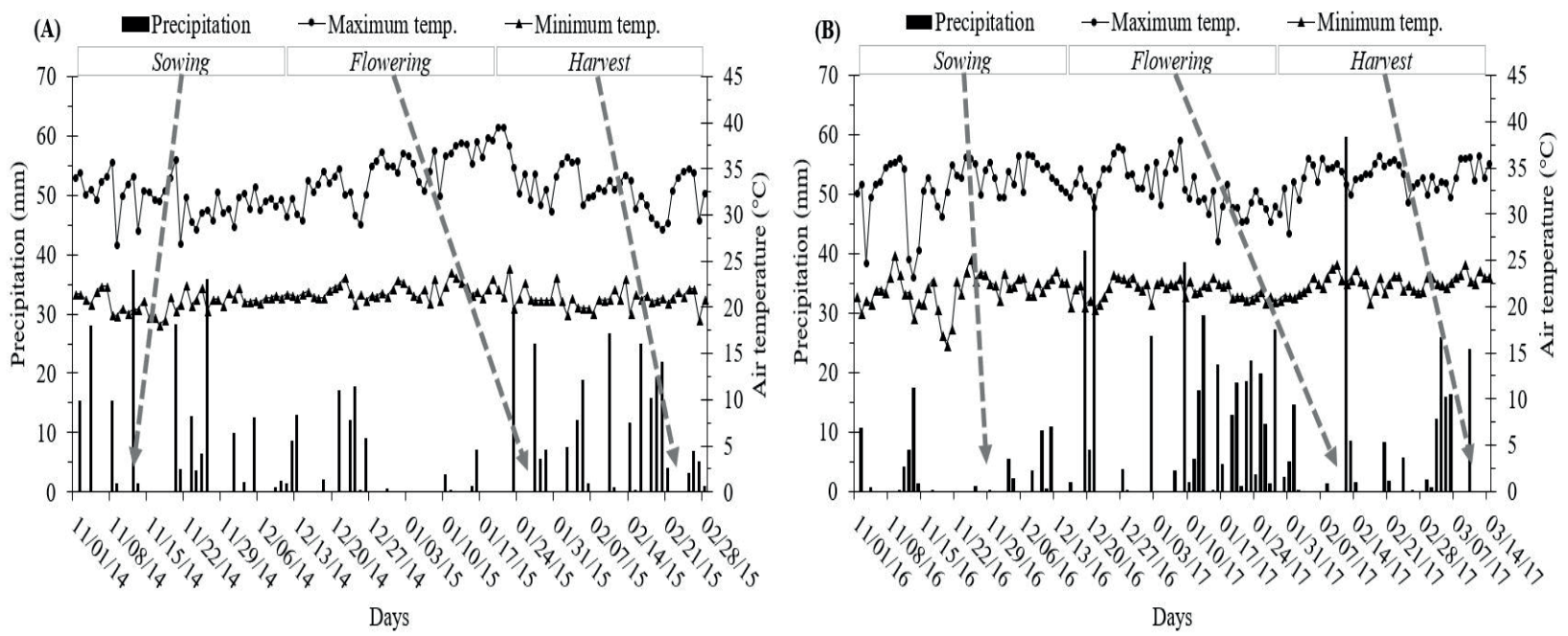

Figure 1. Precipitation ( $\mathrm{mm})$, minimum and maximum air temperature during the upland rice growth (experimental period), in Selvíria, Mato Grosso do Sul state, Brazil, during the 2014/2015 (A) and 2016/2017 (B) growing seasons.

intercropped with corn were sown at $0.45 \mathrm{~m}$ from the corn rows, using 30 viable seeds $\mathrm{m}^{-1}, 15$ viable seeds $\mathrm{m}^{-1}, 7$ viable seeds $\mathrm{m}^{-1}$ and $8 \mathrm{~kg} \mathrm{ha}^{-1}$, respectively.

The soil chemistry in the $0-0.20 \mathrm{~m}$ layer at the experimental field was characterized prior to corn sowing (November 2013), and its analysis showed the following values: $\mathrm{P}_{\text {resin }}=20 \mathrm{mgdm}^{-3} ; \mathrm{OM}=21 \mathrm{~g} \mathrm{dm}^{-3} ; \mathrm{pH}$ $\left(\mathrm{CaCl}_{2}\right)=5.4 ; \mathrm{K}=3.0 \mathrm{mmol} \mathrm{dm}_{\mathrm{c}}^{-3} ; \mathrm{Ca}=28 \mathrm{mmol}_{\mathrm{c}} \mathrm{dm}^{-3}$; $\mathrm{Mg}=21 \mathrm{mmol}_{\mathrm{c}} \mathrm{dm}^{-3} ; \mathrm{SB}=52 \mathrm{mmol}_{\mathrm{c}} \mathrm{dm}^{-3} ; \mathrm{Al}=$ $0 \mathrm{mmol}_{\mathrm{c}} \mathrm{dm}^{-3} ; \mathrm{H}+\mathrm{Al}=24.5 \mathrm{mmol}_{\mathrm{c}} \mathrm{dm}^{-3} ; \mathrm{CEC}=$ $77 \mathrm{mmol}_{\mathrm{c}} \mathrm{dm}^{-3}$; and $\mathrm{V}=67 \%$.

The experiment was designed in randomized blocks arranged in a $5 \times 4$ factorial scheme, and the treatments consisted of a combination of the residual effect of the residues from the previous year (single corn crop, corn + Crotalaria spectabilis, corn + pigeon pea, corn + jack bean and corn + Urochloa ruziziensis) on the development of the upland rice crop, with varying cover nitrogen levels $\left(0 \mathrm{~kg} \mathrm{ha}^{-1}\right.$, $40 \mathrm{~kg} \mathrm{ha}^{-1}, 80 \mathrm{~kg} \mathrm{ha}^{-1}$ and $\left.120 \mathrm{~kg} \mathrm{ha}^{-1}\right)$. Each parcel consisted of 10 rows, being each row with $7.5 \mathrm{~m}$ long and $0.35 \mathrm{~m}$ from each other. The actual area consisted of the eight central rows of each parcel, with $0.50 \mathrm{~m}$ at each end not considered.

The cultivar used was the BRS Esmeralda (grain type fine, long). Seeding was carried out on 11 November 2014 and 29 November 2016. According to Arf et al. (2000), for the highest yield, this is the most suitable month in this region for sowing rice irrigated by sprinkler systems. The seeds were treated with fipronil ( $50 \mathrm{~g}$ of a.i. per $100 \mathrm{~kg}$ of seeds) shortly before sowing to control soil pests. After drying, the seeds were inoculated in the shade with the Azospirillum brasilense strains $\mathrm{Ab}-\mathrm{V}_{5}$ and $\mathrm{Ab}-\mathrm{V}_{6}\left(2 \times 10^{8}\right.$ viable cells $\mathrm{g}^{-1}$ of the commercial product), with $100 \mathrm{~mL}$ of inoculant being applied to $25 \mathrm{~kg}$ of seeds.

The mineral fertilization in the sowing grooves consisted of $200 \mathrm{~kg} \mathrm{ha}^{-1}$ of the formulation 08-28-16, calculated according to the soil chemical characteristics. Urea was used as the source for nitrogen fertilization, applied at 25 days after the plant emergence (DAE) in 2014/2015 and 27 DAE in 2016/2017. After the application, irrigation was performed to minimize $\mathrm{N}$ losses by volatilization.

Irrigation was performed with a fixed sprinkler system. Three crop coefficients (Kc) were used for water management, distributed in four periods between emergence and harvest. A coefficient of 0.40 was used for the vegetative phase, 0.70 for the initial reproductive phase, 1.00 for the late reproductive phase, 1.00 for the initial maturation phase and 0.70 for the final maturation.

Weed control included the use of herbicides by trailed sprayer. Because Digitaria sanguinalis and Cenchrus echinatus had been observed frequently in the experimental area, pendimethalin $\left(1.400 \mathrm{~g} \mathrm{ha}^{-1}\right.$ of a.i.) was applied immediately after sowing. After the plant emergence, metsulfuron methyl $\left(2 \mathrm{~g} \mathrm{ha}^{-1}\right.$ of a.i.) was applied to control broad leaf weeds. This procedure was repeated in both years. Other weeds 
not controlled by herbicides were removed using a hoe.

Panicle formation reached $50 \%$ on 26 January 2015 and 13 February 2017, at 71 and 70 DAE, respectively. Harvest was carried out on 24 February 2015 and 13 March 2017, at 100 and 98 DAE, respectively. The total dry mass was assessed to determine the soil coverage, $\mathrm{N}$ content and $\mathrm{C} / \mathrm{N}$ ratio. After the corn harvest (March 2014 and 2016), the area was dried out and prepared using a mechanical crusher, to facilitate the collection of crop residues from the soil. Subsequently, the dry mass was collected from the area within a $0.25 \mathrm{~m}^{2}$ square at two points per plot and, after drying, the plant material was weighed and the value was extrapolated to one hectare.

Assessments were then performed for the following: $\mathrm{N}$ content and $\mathrm{C} / \mathrm{N}$ ratio (single corn crop or intercropped), rice dry mass (collected at $0.6 \mathrm{~m}$ per row at the flowering stage, at two points per plot, and, after drying, the weight was extrapolated to hectare), leaf $\mathrm{N}$ content (based on 20 flag leaves from each parcel collected at the flowering stage, dried, crushed and evaluated in the laboratory), plant height (average distance from the soil surface to the highest extremity of the highest panicle, for 10 random plants), number of panicles $\mathrm{m}^{-2}$ (counting the number of panicles in $1.0 \mathrm{~m}$ of a plant row, and then extrapolating to panicles $\mathrm{m}^{-2}$ ), number of grainfilled spikelets per panicle (number of grains in 20 panicles collected at harvest), 100-grain mass (mass of two samples of one hundred grains) and grain yield (mass of grains produced by the used area in $\left.\mathrm{kg} \mathrm{ha}^{-1}\right)$. Mass values were corrected for $13 \%$ of moisture (wet basis).
The data were initially submitted to variance analysis, polynomial regression analysis for the quantitative factor (nitrogen dose) and the Tukey test for the qualitative factor (plant residue).

\section{RESULTS AND DISCUSSION}

Treatments with intercropped corn presented a higher dry mass than treatments with the single corn crop (Table 1). The 2-year average production under intercropping with Crotalaria spectabilis, pigeon pea, jack bean and Urochloa ruziziensis were, respectively, 2,032 $\mathrm{kg} \mathrm{ha}^{-1}, 4,496 \mathrm{~kg} \mathrm{ha}^{-1}, 1,978 \mathrm{~kg} \mathrm{ha}^{-1}$ and $3,952 \mathrm{~kg} \mathrm{ha}^{-1}$ greater than that with the single corn crop. Corn residues are important for the maintenance of no-tillage systems. However, the increase in dry mass, associated with the intercropped species, resulted in better conditions for direct planting, with a better soil coverage and nutrient cycling, thus favoring the subsequent crops. According to Ceretta et al. (2002), the success of a no-tillage system depends on the production of sufficient dry mass for soil coverage. This is similar to the findings published by Gitti et al. (2012b), who evaluated corn as a single crop and intercropped with Crotalaria spectabilis and Crotalaria juncea, in varying sowing periods, and observed an increase in dry mass of $1,320 \mathrm{~kg} \mathrm{ha}^{-1}$ and 6,670 $\mathrm{kg} \mathrm{ha}^{-1}$, respectively when Crotalaria spectabilis and Crotalaria juncea were planted simultaneously with corn. Those authors highlighted that the intercropped species increase the nutrient availability to the cropping system.

In the first year of the experiment, the residues of the intercropping of corn with jack bean resulted

Table 1. Total plant dry mass, nitrogen content and $\mathrm{C} / \mathrm{N}$ ratio of residues of single corn crop and intercropped corn (with grasses or legumes) after harvest.

\begin{tabular}{|c|c|c|c|c|c|c|}
\hline \multirow[t]{2}{*}{ Treatments } & \multicolumn{2}{|c|}{$\begin{array}{c}\text { Total dry mass } \\
\left(\mathrm{kg} \mathrm{ha}^{-1}\right)\end{array}$} & \multicolumn{2}{|c|}{$\begin{array}{c}\text { N content } \\
\left(\mathrm{g} \mathrm{kg}^{-1}\right)\end{array}$} & \multicolumn{2}{|c|}{$\mathrm{C} / \mathrm{N}$ ratio } \\
\hline & $2013 / 2014$ & $2015 / 2016$ & $2013 / 2014$ & $2015 / 2016$ & $2013 / 2014$ & $2015 / 2016$ \\
\hline Corn & $8,654 \mathrm{~b}$ & $6,827 \mathrm{~b}$ & $6.05 \mathrm{~b}$ & $8.85 \mathrm{~b}$ & $78 \mathrm{a}$ & $48 \mathrm{a}$ \\
\hline Corn + C. spectabilis & $11,167 \mathrm{a}$ & $8,377 \mathrm{~b}$ & $8.36 \mathrm{ab}$ & $12.68 \mathrm{a}$ & $56 \mathrm{ab}$ & $36 a b$ \\
\hline Corn + pigeon pea & $12,569 \mathrm{a}$ & $11,904 \mathrm{a}$ & $8.85 \mathrm{ab}$ & $13.80 \mathrm{a}$ & $52 \mathrm{ab}$ & $31 \mathrm{~b}$ \\
\hline Corn + jack beans & $11,062 \mathrm{a}$ & $8,374 \mathrm{~b}$ & $9.37 \mathrm{a}$ & $12.73 \mathrm{a}$ & $49 \mathrm{~b}$ & $36 \mathrm{ab}$ \\
\hline Corn $+U$. ruziziensis & $12,590 \mathrm{a}$ & $10,795 \mathrm{a}$ & $7.47 \mathrm{ab}$ & $10.70 \mathrm{ab}$ & $63 \mathrm{ab}$ & $40 \mathrm{ab}$ \\
\hline F value & $10.56^{* *}$ & $25.61 * *$ & $3.36^{*}$ & $7.18 * *$ & $3.51 *$ & $3.51 *$ \\
\hline MSD & 2,227 & 1,827 & 3.25 & 3.31 & 27.9 & 14.86 \\
\hline $\mathrm{CV}(\%)$ & 8.81 & 8.76 & 18.01 & 12.51 & 20.8 & 17.29 \\
\hline
\end{tabular}


in an increase of $55 \%$ in the nitrogen content, if compared to the single corn crop residues (Table 1). In the second year, the residues of corn intercropped with legumes presented an average of $48 \%$ more nitrogen than the single corn crop residues. The association of corn + legumes favors the availability of nitrogen, as legumes fix atmospheric $\mathrm{N}_{2}$ and introduce it into the crop nutrient cycle (Kappes \& Zancanaro 2015).

The most contrasting $\mathrm{C} / \mathrm{N}$ ratios were observed in the treatments with single corn crop, relatively to the treatments corn + jack bean in 2013/2014 and corn + pigeon pea in 2015/2016 (Table 1). This occurred because a smaller $\mathrm{C} / \mathrm{N}$ ratio is present when a grassy species and a legume are intercropped than when the grassy species is grown by itself (Andreola et al. 2000). Oliveira et al. (2010) cite the association between corn and green manure with dwarf pigeon pea (Cajanus cajan) or crotalaria (Crotalaria spectabilis) in the Santa Brigida system as an example of success, aiming to validate these technologies and promote their use for integration among crops, livestock and forest systems.

No significant differences existed in the plant dry mass between the single crop and intercropped corn at the time of flowering (Table 2). An increase in the rice plant dry mass could result in an increased grain yield; however, the most important factors influencing yield are cultivar, planting density and fertilization (Fageria 1989). Thus, the likely benefits in the production of dry mass of rice plants, seeded in rotation with single crop or corn intercropped with grassy and legume species, may be observed in future rotation cycles, where treatments with a greater accumulation of dry mass and nutrients can stand out. Gitti et al. (2012a), studying the accumulation of dry matter of upland rice, also did not detect significant effects of cultivation in succession with cover crops.

For the coverage with $\mathrm{N}$, the dry matter production data of the rice plants fitted a linear function, reaching $11,140 \mathrm{~kg} \mathrm{ha}^{-1}$ and $8,626 \mathrm{~kg} \mathrm{ha}^{-1}$, respectively with the application of $120 \mathrm{~kg} \mathrm{ha}^{-1}$ of $\mathrm{N}$ for the first and second crop years (Figure 2A). The high $\mathrm{C} / \mathrm{N}$ ratio of the plant residue suggests that the nitrogen may have been immobilized. Thus, increasing doses of this nutrient may supply nitrogen to the soil microflora and make more nitrogen available for the rice plants. Gitti et al. (2012a) and Stone et al. (1999) also observed an increase in rice plant dry mass, in association with higher amounts of applied $\mathrm{N}$ doses.

The $\mathrm{N}$ content in the leaves of rice plants in the second year significantly differed between the intercropped corn + jack bean and single corn crop (Table 2). This difference is due to the higher accumulation of $\mathrm{N}$ by the corn + jack bean residues (106 $\mathrm{kg} \mathrm{ha}^{-1}$ ), which increased the availability of the nutrient, if compared to the single corn crop $\left(60 \mathrm{~kg} \mathrm{ha}^{-1}\right)$. For the uptake of nitrogen fertilizer and cover crops for upland rice, Silva et al. (2016) determined that, with accumulations of $196 \mathrm{~kg} \mathrm{ha}^{-1}$ of nitrogen in Crotalaria juncea and $84 \mathrm{~kg} \mathrm{ha}^{-1}$ in millet plants, of the total nitrogen content in rice plants sowed in succession with Crotalaria, $74.1 \%$

Table 2. Rice plant dry mass, leaf $\mathrm{N}$ content and plant height for upland rice planted in succession with single corn crop or corn intercropped with grassy or legume species, as a function of applied nitrogen doses.

\begin{tabular}{|c|c|c|c|c|c|c|}
\hline \multirow[t]{2}{*}{ Treatments } & \multicolumn{2}{|c|}{$\begin{array}{l}\text { Plant dry mass } \\
\left(\mathrm{kg} \mathrm{ha}^{-1}\right)\end{array}$} & \multicolumn{2}{|c|}{$\begin{array}{l}\text { Leaf N } \\
\left(\mathrm{g} \mathrm{kg}^{-1}\right)\end{array}$} & \multicolumn{2}{|c|}{$\begin{array}{l}\text { Plant height } \\
(\mathrm{cm})\end{array}$} \\
\hline & $2014 / 2015$ & $2016 / 2017$ & $2014 / 2015$ & $2016 / 2017$ & $2014 / 2015$ & $2016 / 2017$ \\
\hline \multicolumn{7}{|l|}{ Cover crops } \\
\hline Corn & 9,773 & 6,765 & 37.2 & $29.4 \mathrm{~b}$ & 109.5 & 91.8 \\
\hline Corn + C. spectabilis & 10,019 & 7,296 & 36.7 & $30.4 \mathrm{ab}$ & 107.9 & 97.3 \\
\hline Corn + pigeon pea & 10,198 & 7,773 & 37.1 & $30.2 \mathrm{ab}$ & 107.7 & 97.2 \\
\hline Corn + jack bean & 10,435 & 7,774 & 37.4 & $31.3 \mathrm{a}$ & 109.9 & 97.4 \\
\hline Corn $+U$. ruziziensis & 9,915 & 7,825 & 36.6 & $30.9 \mathrm{ab}$ & 108.7 & 93.3 \\
\hline \multicolumn{7}{|l|}{$F$ value } \\
\hline Cover crops & $0.46^{\mathrm{ns}}$ & $2.08^{\mathrm{ns}}$ & $0.96^{\mathrm{ns}}$ & $3.49 * *$ & $1.21^{\mathrm{ns}}$ & $5.29 * *$ \\
\hline $\mathrm{N}$ doses & $10.04 * *$ & $8.78 * *$ & $8.07 * *$ & $8.01 *$ & $89.35 * *$ & $16.89 * *$ \\
\hline Cover vs. N & $0.68^{\mathrm{ns}}$ & $1.31^{\mathrm{ns}}$ & $0.73^{\mathrm{ns}}$ & $0.51^{\mathrm{ns}}$ & $0.58^{\mathrm{ns}}$ & $3.11 * *$ \\
\hline MSD for cover & - & - & - & 1.58 & - & 4.67 \\
\hline CV (\%) & 13.03 & 14.67 & 3.64 & 4.45 & 3.29 & 4.19 \\
\hline
\end{tabular}

**, * and ${ }^{\mathrm{ns}}$ significant at $1 \%$ and $5 \%$ of probability and not significant, respectively, by the $\mathrm{F}$ test. Mean values followed by the same letters are equivalent, based on the Tukey test at $5 \%$ of probability. MSD: minimum significant difference; CV: coefficient of variation. 
originated from the soil, $14.9 \%$ from the crotalaria residue and $10 \%$ from the fertilizer, while, for the rice sowed in succession with millet, $78.8 \%$ originated from the soil, $7 \%$ from the millet residue and $14.2 \%$ from the fertilizer.

On the other hand, the data obtained for the $\mathrm{N}$ cover application fitted a linear equation showing an increase over the 2 years of cultivation (Figure 2B). The same pattern was reported by Cazetta et al. (2008) and Gitti et al. (2012a), for upland rice. This finding is likely due to an increase in the productive potential associated with the crop rotation system, which makes the plants use more nutrients, especially nitrogen, what is reflected in the higher $\mathrm{N}$ content in the leaves. According to Troeh \& Thompson (2007), plants uptake nitrogen when they are in active growth. Therefore, the nitrogen deficiency could decrease growth and yield. It is important to point out that, even in treatments where $\mathrm{N}$ was not applied, the values obtained for the content of foliar nitrogen are within the range of 27-35 $\mathrm{g} \mathrm{kg}^{-1}$, which is considered suitable for the crop (Cantarella \& Furlani 1996).
The cover $\mathrm{N}$ doses produced an increase in plant height, in the first year of cultivation (Table 2), and the data fitted a linear function, in which the rice plants reached $115.5 \mathrm{~cm}$ at a dose of $120 \mathrm{~kg} \mathrm{ha}^{-1}$ (Figure 2C). Nitrogen is the primary nutrient responsible for plant growth (Basuchaudhuri 2016); however, when supplied in excess, it may cause plants to grow excessively and lead to lodging. According to Arf et al. (2012), rice plants hamper mechanized harvesting. Even though a linear growth of the rice plants was observed due to the increase in the nitrogen supply, in the present experiment, no plant lodging occurred, and these results are similar to those obtained by Goes et al. (2016).

A significant interaction between cover crops and nitrogen doses was found in the second year (Table 2). The data for all treatments with single corn crop or intercropped corn were fitted to linear models (Figure 2D), similarly to the results described in Cazetta et al. (2008) and Gitti et al. (2012a). Notably, when no nitrogen cover was applied, the use of corn + pigeon pea produced taller plants, when compared
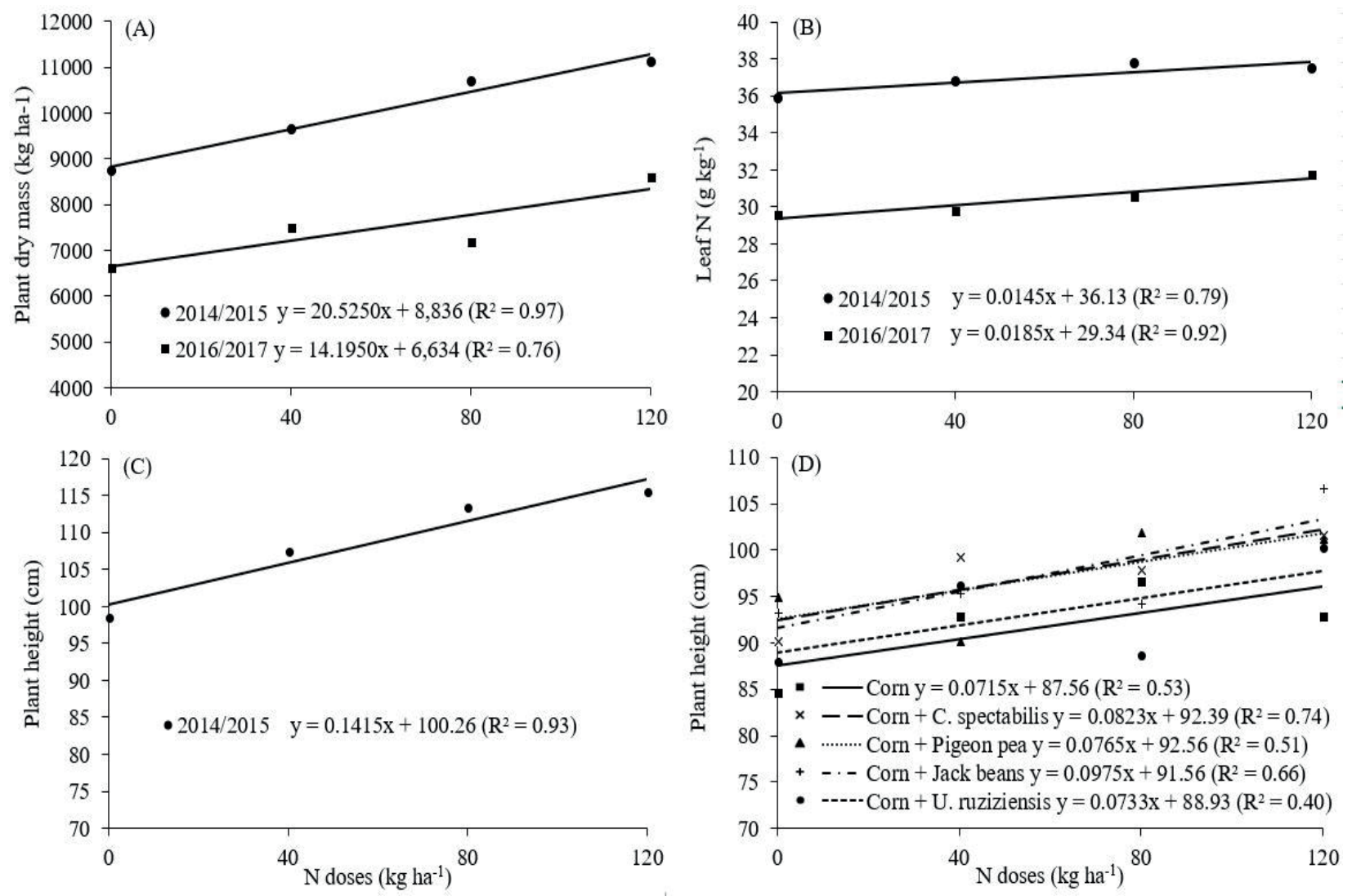

Figure 2. Plant dry mass (A), leaf $N$ content (B) and plant height in 2014/2015 (C), and interaction of the plant height of upland rice, as a function of cover crops and $\mathrm{N}$ doses in 2016/2017 (D). 
to the single corn crop. Thus, these results suggest that better growth conditions are created when rice is planted in succession with corn + pigeon pea.

With the application of $80 \mathrm{~kg} \mathrm{ha}^{-1}$ of $\mathrm{N}$, the rotation with corn + pigeon pea resulted again in taller plants, even taller than those produced with corn + U. ruziziensis. With the application of $120 \mathrm{~kg} \mathrm{ha}^{-1}$ of $\mathrm{N}$, corn + jack bean resulted in taller plants than with the single corn crop. Thus, rice plant height was favored in the rotation systems using corn + leguminous species, if compared to the single corn crop and corn intercropped with $U$. ruziziensis. This increase occurred because of the nitrogen input associated with the intercropped leguminous plant residues, in addition to the applied doses. Silva et al. (2016) also mentioned that leguminous plants contributed with more nitrogen for rice plants than did grassy cover crops.

The highest number of panicles $\mathrm{m}^{-2}$ was obtained in the second year with corn + pigeon pea, when compared to corn + Crotalaria spectabilis (Table 3). The dry mass accumulated by the corn + pigeon pea residues was $3,527 \mathrm{~kg} \mathrm{ha}^{-1}$ greater than that obtained with corn + Crotalaria spectabilis. Thus, the increased soil coverage provided a better temperature control (smaller temperature variations), favoring the production of rice panicles.

In the first year, the rotation of corn + pigeon pea also produced $12 \%$ more grain-filled spikelets per panicle than did corn $+U$. ruziziensis (Table 3). Corn + pigeon pea also accumulated more dry mass and $113 \%$ and $18 \%$ more nitrogen in the residues than did the single corn crop and corn + U. ruziziensis, respectively. In the second year, corn + pigeon pea and corn $+U$. ruziziensis produced an average increase of $14.5 \%$ in the number of grain-filled spikelets, if compared to the single corn crop. In that period, the residues of corn + pigeon pea accumulated $173 \%$ more nitrogen and those of corn $+U$. ruziziensis accumulated $92 \%$ more nitrogen than did the single corn crop. Thus, the variation in the accumulation of nitrogen by the different treatments might explain the variation in the number of grain-filled spikelets per panicle. The summer rotation of corn + pigeon pea may therefore provide better conditions for the development of rice in the following year, when compared to the single corn crop.

Increased $\mathrm{N}$ doses were associated, in the first year, with increases in the number of panicles $\mathrm{m}^{-2}$ (Figure 3A), whereas the number of grain-filled spikelets per panicle decreased $10 \%$ with the application of $120 \mathrm{~kg} \mathrm{ha}^{-1}$ of $\mathrm{N}$, when compared to no application (Figure 3B). Cazetta et al. (2008) also observed a decrease of $9.4 \%$ in the number of filled spikelets with increases in the application of $\mathrm{N}$ doses. The increase in the number of panicles could be associated with less translocation of elaborated sap for the adequate filling of the spikelets. Crusciol et al. (2003) also reported that a lower number of panicles lead to a higher number of spikelets.

Both components were fitted to quadratic functions in the second year, with a maximum under the application of $77 \mathrm{~kg} \mathrm{ha}^{-1}$ and $100 \mathrm{~kg} \mathrm{ha}^{-1}$ of $\mathrm{N}$ (Figures 3A and 3B), respectively for the two

Table 3. Number of panicles $\mathrm{m}^{-2}$ and number of grain-filled spikelets per panicle in upland rice planted in succession with single corn crop or corn intercropped with grassy or legume species, as a function of applied nitrogen doses.

\begin{tabular}{|c|c|c|c|c|}
\hline \multirow{2}{*}{ Treatments } & \multicolumn{2}{|c|}{ Panicles $\mathrm{m}^{-2}$} & \multicolumn{2}{|c|}{ Grain-filled spikelets per panicle } \\
\hline & $2014 / 2015$ & $2016 / 2017$ & $2014 / 2015$ & $2016 / 2017$ \\
\hline \multicolumn{5}{|l|}{ Cover crops } \\
\hline Corn & 301 & $242 \mathrm{ab}$ & $114.0 \mathrm{~b}$ & $104.4 \mathrm{~b}$ \\
\hline Corn + C. spectabilis & 295 & $232 \mathrm{~b}$ & $117.3 \mathrm{ab}$ & $109.3 \mathrm{ab}$ \\
\hline Corn + pigeon pea & 297 & $266 \mathrm{a}$ & $127.3 \mathrm{a}$ & $119.9 \mathrm{a}$ \\
\hline Corn + jack beans & 306 & $236 a b$ & $116.8 \mathrm{ab}$ & $116.7 \mathrm{ab}$ \\
\hline Corn + U. ruziziensis & 291 & $243 \mathrm{ab}$ & $113.4 \mathrm{~b}$ & $119.3 \mathrm{a}$ \\
\hline \multicolumn{5}{|l|}{ Fvalue } \\
\hline Cover crops & $0.44^{\mathrm{ns}}$ & $2.66^{*}$ & $2.34 *$ & $4.16^{* *}$ \\
\hline $\mathrm{N}$ doses & $5.00 * *$ & $4.37 * *$ & $2.67 *$ & $9.94 * *$ \\
\hline Cover vs. $\mathrm{N}$ & $1.39^{\mathrm{ns}}$ & $2.03^{\mathrm{ns}}$ & $1.02^{\mathrm{ns}}$ & $2.13^{\text {ns }}$ \\
\hline MSD for cover & - & 33.16 & - & 13.50 \\
\hline CV (\%) & 11.27 & 11.64 & 12.37 & 10.14 \\
\hline
\end{tabular}


evaluated features. The results suggest a positive correlation between the number of panicles $\mathrm{m}^{-2}$ and the number of spikelets per panicle, as suggested by Dalchiavon et al. (2012). Goes et al. (2016) also observed a quadratic response to the number of panicles $\mathrm{m}^{-2}$ (maximum of $74 \mathrm{~kg} \mathrm{ha}^{-1}$ and $106 \mathrm{~kg} \mathrm{ha}^{-1}$ of $\mathrm{N}$ for the first and second experiments, respectively).

The cover crops used in the previous summer season did not affect the 100-grain mass during the two years of this experiment, or the yield during the first year (Table 4). For the second year, corn + pigeon pea led to a $15 \%$ increase in the upland rice yield, if compared to the single corn crop. For that year, the plant dry mass of corn + pigeon pea and the accumulated nitrogen, which is the product of the dry mass and nitrogen content, were $74 \%$ and $178 \%$ higher than the accumulated nitrogen obtained with the single corn crop, respectively. The $\mathrm{C} / \mathrm{N}$ ratio was $35 \%$ lower in corn + pigeon pea. Thus, with the increased accumulation of $\mathrm{N}$ and smaller $\mathrm{C} / \mathrm{N}$ ratio, the intercropped treatment corn + pigeon pea favored the rice yield. According to Dalla Chieza et al. (2013), this intercropping practice presents a great potential for improving the physical soil characteristics.

Nitrogen fertilization decreased the 100-grain mass in both years of the experiment, and the data
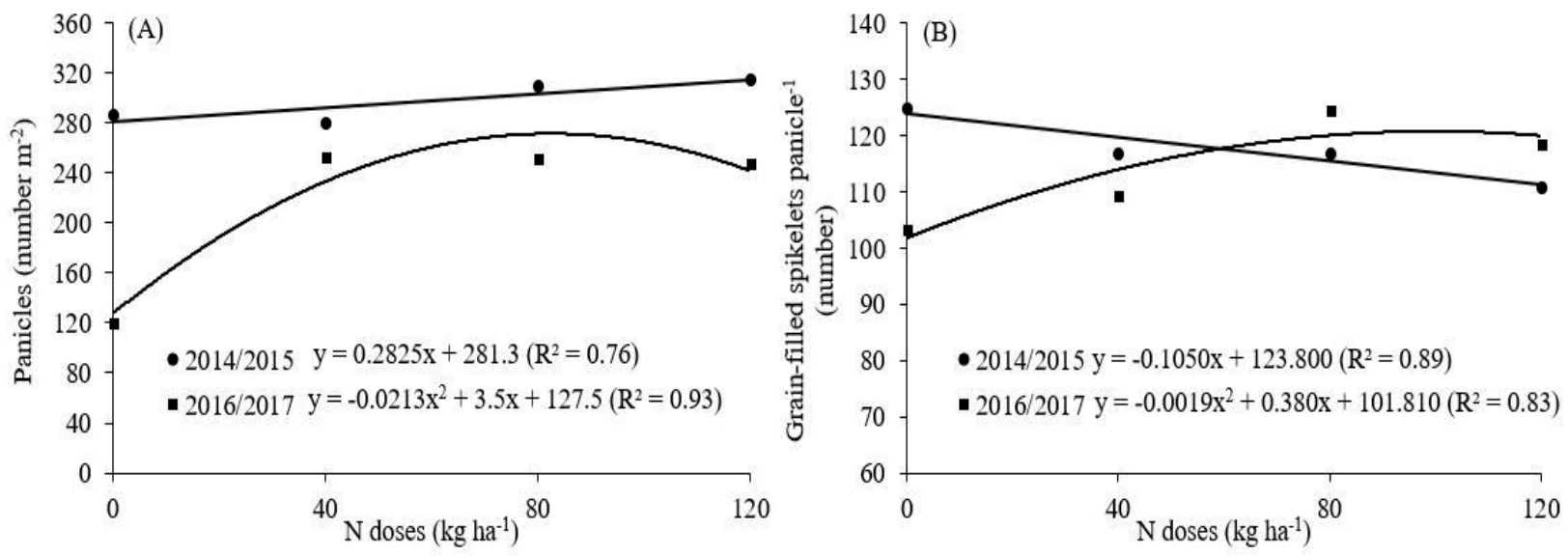

Figure 3. Number of panicles $\mathrm{m}^{-2}(\mathrm{~A})$ and number of grain-filled spikelets per panicle (B) in upland rice, as affected by nitrogen doses, in 2014/2015 and 2016/2017.

Table 4. One hundred-grain mass and yield for upland rice planted in succession with single corn crop or corn intercropped with grassy or legume species, as a function of applied nitrogen doses.

\begin{tabular}{|c|c|c|c|c|}
\hline \multirow{3}{*}{ Treatments } & \multicolumn{2}{|c|}{ 100-grain mass } & \multicolumn{2}{|c|}{ Grain yield } \\
\hline & \multicolumn{2}{|c|}{$\mathrm{g}$} & \multicolumn{2}{|c|}{$\mathrm{kg} \mathrm{ha}^{-1}$} \\
\hline & $2014 / 2015$ & $2016 / 2017$ & $2014 / 2015$ & $2016 / 2017$ \\
\hline \multicolumn{5}{|l|}{ Cover crops } \\
\hline Corn & 2.48 & 2.74 & 5,319 & $4,997 \mathrm{~b}$ \\
\hline Corn + C. spectabilis & 2.45 & 2.70 & 5,243 & $5,108 \mathrm{ab}$ \\
\hline Corn + pigeon pea & 2.44 & 2.63 & 5,021 & $5,740 \mathrm{a}$ \\
\hline Corn + jack bean & 2.44 & 2.66 & 5,101 & $5,506 \mathrm{ab}$ \\
\hline Corn + U. ruziziensis & 2.45 & 2.67 & 4,066 & $5,580 \mathrm{ab}$ \\
\hline \multicolumn{5}{|l|}{ Fvalue } \\
\hline Cover crops & $0.16^{\mathrm{ns}}$ & $2.00^{\mathrm{ns}}$ & $0.94^{\mathrm{ns}}$ & $3.07 *$ \\
\hline $\mathrm{N}$ doses & $5.60 * *$ & $5.20 * *$ & $2.23 *$ & $12.93 * *$ \\
\hline Cover vs. $\mathrm{N}$ & $0.82^{\text {ns }}$ & $2.22^{\mathrm{ns}}$ & $0.77^{\mathrm{ns}}$ & $1.19^{\mathrm{ns}}$ \\
\hline MSD cover & - & - & - & 735.91 \\
\hline $\mathrm{CV}(\%)$ & 6.30 & 3.75 & 11.86 & 11.69 \\
\hline
\end{tabular}



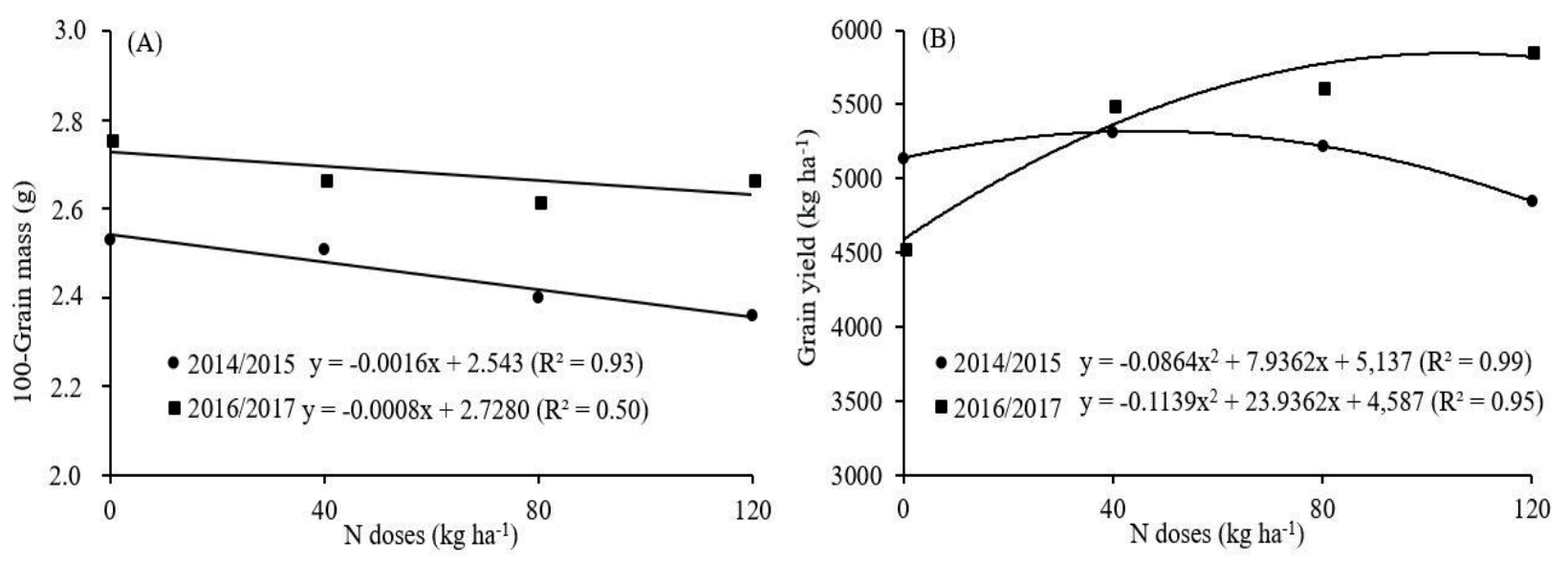

Figure 4. One hundred-grain mass (A) and grain yield (B) of upland rice, as affected by nitrogen doses, in 2014/2015 and 2016/2017.

fitted the linear functions (Figure 4A). Possibly, with the higher production of panicles per area, an increased competition for nutrients occurs and, thus, the supply of nutrients necessary for grain filling to occur was insufficient. Nascimento et al. (2013) also recorded a decrease in the 100-grain mass with an increase in the dose of applied nitrogen.

Grain yield data fitted the quadratic functions in both years of the experiment, with maximum values estimated at $46 \mathrm{~kg} \mathrm{ha}^{-1}$ and $105 \mathrm{~kg} \mathrm{ha}^{-1}$ of applied nitrogen (Figure 4B), respectively. Nascimento et al. (2013) and Goes et al. (2016) also verified that the highest yields were associated with a relatively low dose of applied nitrogen: $69 \mathrm{~kg} \mathrm{ha}^{-1}$ and $50 \mathrm{~kg} \mathrm{ha}^{-1}$, respectively. However, Gitti et al. (2012a) observed the highest rice grain yield with the dose of $107 \mathrm{~kg} \mathrm{ha}^{-1}$ of N. A no-tillage system that uses crop rotation and green manure favors an increase in the rice yield potential. Thus, in the second year, in the absence of nitrogen applications, a decrease of $12 \%$ occurred in grain yield, when compared to the first year. However, with higher doses, during the second year, the rice crop responded with a greater increase in yield.

Notably, the crop rotation influenced most of the studied variables in the second cycle. The potential benefits inherent to the rotation of intercropped crops and upland rice may intensify with the establishment of the system. According to Fidelis et al. (2003), among the main benefits of crop rotation are the maintenance and improvement of soil attributes and crop yield. Our results suggest that the improvement of upland rice production and yield may be achieved in rotation systems with corn + pigeon pea, as this cover crop favors a greater accumulation of dry mass and nitrogen, in addition to providing a greater number of grain-filled spikelets per panicle, culminating in higher yields of upland rice grains, if compared to the single corn crop.

\section{CONCLUSIONS}

1. The cultivation of corn + pigeon pea resulted in a $15 \%$ increase in the yield of rice grains sowed in a rotation system, if compared to the single corn crop;

2. In a system irrigated by sprinkling, the application of nitrogen at an estimated dose of $46 \mathrm{~kg} \mathrm{ha}^{-1}$ and $105 \mathrm{~kg} \mathrm{ha}^{-1}$, respectively for the harvest years of 2014/2015 and 2016/2017, positively influenced the grain yield for the rice cultivar BRS Esmeralda.

\section{ACKNOWLEDGMENTS}

The authors would like to thank the Fundação de Amparo à Pesquisa do Estado de São Paulo (FAPESP, Proc. 2013/19603-7) and the Conselho Nacional de Desenvolvimento Científico e Tecnológico (CNPq, Proc. 302.827/2013-7).

\section{REFERENCES}

ANDRADE, R. S. et al. Culturas de cobertura e qualidade física de um Latossolo em plantio direto. Revista Brasileira de Engenharia Agrícola e Ambiental, v. 13, n. 4, p. 411418, 2009. 
ANDREOLA, F. et al. A cobertura vegetal de inverno e a adubação orgânica e, ou, mineral influenciando a sucessão feijão/milho. Revista Brasileira de Ciência do Solo, v. 24, n. 4, p. 867-874, 2000.

ARF, O. et al. Influência da época de semeadura no comportamento de cultivares de arroz irrigado por aspersão em Selvíria, MS. Pesquisa Agropecuária Brasileira, v. 35, n. 10, p. 1967-1976, 2000.

ARF, O. et al. Uso de etil-trinexapac em cultivares de arroz de terras altas. Pesquisa Agropecuária Tropical, v. 42, n. 2 , p. 150-158, 2012.

BASUCHAUDHURI, P. Nitrogen metabolism in rice. Boca Raton: CRC Press, 2016.

CANTARELLA, H.; FURLANI, P. R. Arroz de sequeiro. In: RAIJ, B. V. et al. (Coords.). Recomendações de adubação e calagem para o Estado de São Paulo. 2. ed. Campinas: Instituto Agronômico/Fundação IAC, 1996. p. 46-47.

CAZETTA, D. A. et al. Desempenho do arroz de terras altas com a aplicação de doses de nitrogênio e em sucessão às culturas de cobertura do solo em sistema de plantio direto. Bragantia, v. 67, n. 2, p. 471-479, 2008.

CERETTA, C. A. et al. Manejo da adubação nitrogenada na sucessão aveia preta/milho, no sistema plantio direto. Revista Brasileira de Ciência do Solo, v. 26, n. 1, p. 163171, 2002.

CRUSCIOL, C. A. C. et al. Produtividade do arroz de terras altas sob condições de sequeiro e irrigado por aspersão em função do espaçamento entre fileiras. Agronomia, v. 37, n. 1, p. 10-15, 2003.

DALCHIAVON, F. C. et al. Correlação linear entre componentes da produção e produtividade do arroz de terras altas em sistema plantio direto. Semina: Ciências Agrárias, v. 33, n. 5, p. 1629-1642, 2012.

DALLA CHIEZA, E. et al. Propriedades físicas do solo em área sob milho em monocultivos ou consorciado com leguminosas de verão. Revista Brasileira de Ciência do Solo, v. 37, n. 5, p. 1393-1401, 2013.

FAGERIA, N. K. et al. Nitrogen uptake and use efficiency in upland rice under two nitrogen sources. Communications in Soil Science and Plant Analysis, v. 45, n. 4, p. 461-469, 2014.

FAGERIA, N. K. Solos tropicais e aspectos fisiológicos das culturas. Brasília, DF: Embrapa, 1989.

FIDELIS, R. R. et al. Alguns aspectos do plantio direto para a cultura da soja. Bioscience Journal, v. 19, n. 1, p. 23-31, 2003.
GITTI, D. C. et al. Coberturas vegetais, doses de nitrogênio e inoculação de sementes com Azospirillum brasilense em arroz de terras altas no sistema plantio direto. Bragantia, v. 71, n. 4, p. 509-517, 2012 a.

GITTI, D. C. et al. Épocas de semeadura de crotalária em consórcio com milho. Revista Brasileira de Milho e Sorgo, v. 11, n. 2, p. 156-168, 2012 b.

GOES, R. J. et al. Manejo do nitrogênio em cobertura no arroz de terras altas em sistema plantio direto. Revista Agrarian, v. 9, n. 31, p. 11-18, 2016.

KAPPES, C.; ZANCANARO, L. Sistemas de consórcio de braquiária e de crotalárias com a cultura do milho. Revista Brasileira de Milho e Sorgo, v. 14, n. 2, p. 219234, 2015.

NASCIMENTO, V. et al. Mecanismos de abertura do sulco e da adubação nitrogenada em arroz de terras altas. Revista Ceres, v. 60, n. 6, p. 802-810, 2013.

OLIVEIRA, P. et al. Sistema Santa Brígida: tecnologia Embrapa: consorciação de milho com leguminosas. Santo Antônio de Goiás: Embrapa Arroz e Feijão, 2010.

PACHECO, L. P. et al. Produção e ciclagem de nutrientes por plantas de cobertura nas culturas de arroz de terras altas e de soja. Revista Brasileira de Ciência do Solo, v. 35, n. 5, p. 1787-1799, 2011.

SANTOS, H. G. et al. Sistema brasileiro de classificação de solos. 3. ed. Brasília, DF: Embrapa, 2013.

SILVA, A. A. D. et al. Sistemas de coberturas de solo no inverno e seus efeitos sobre o rendimento de grãos do milho em sucessão. Ciência Rural, v. 37, n. 4, p. 928935, 2007.

SILVA, E. C. et al. Use of nitrogen from fertilizer and cover crops by upland rice in an Oxisol under no-tillage in the Cerrado. Pesquisa Agropecuária Brasileira, v. 51, n. 6, p. 728-737, 2016.

STONE, L. F. et al. Adubação nitrogenada em arroz sob irrigação suplementar por aspersão. Pesquisa Agropecuária Brasileira, v. 34, n. 6, p. 927-932, 1999.

TORRES, J. L. R. et al. Produção de fitomassa por plantas de cobertura e mineralização de seus resíduos em plantio direto. Pesquisa Agropecuária Brasileira, v. 43, n. 3, p. 421-428, 2008.

TROEH, R. F.; THOMPSON, L. M. Solos e fertilidade do solo. São Paulo: Andrei, 2007.

UNITED STATES DEPARTMENT OF AGRICULTURE (USDA). Keys to soil taxonomy. 12. ed. Washington, DC: USDA-Natural Resources Conservation Service, 2014. 